\title{
SOME REMARKS ON THE NILOTIC NEGRO AND A REVIEW OF MR. WESTERMANN'S SHILLUK PEOPLE
}

THE intimate connexion between geographical conditions and the development of mankind is well recognised. As a rule the effect on History of a great mountain range or a mighty river is difficult to over-estimate. The Nile has been the predominant factor in the development of Egypt; like all great highways, it has been the means of facilitating intercourse and trading between the various peoples who dwelt along its banks, but the Nile presents this curious feature, that, for the first thousand miles of its course it flows through lands whose geographical conditions are totally different from those obtaining in its further progress to the sea. At a point some 200 miles $^{1}$ south of Khartum the river emerges from sudd and semi-tropical vegetation, and from here onward the land is a parched and arid desert. To this fact, I am inclined to believe, we may principally ascribe the survival of the Nile negro. At first sight this may appear a paradox, but in reality it is not so, for the climate in the desert is as wholesome and invigorating as it is evil and plague-stricken in the sudd region, and the slime deposited by the river after its annual rise has enabled man to reclaim the natural desert for some distance on either bank. As long as the surroundings of primitive man remained unaltered, no change was possible, and that conditions have remained unchanged for vast periods of time in the Upper Nile Valley is beyond question; such changes as occurred were due to invasions, either of pastoral tribes following their flocks, or of tribes driven south and east themselves, by the

I I cunnot remember the exact plece, but somewhere between Gebelain and Konti. 
pressure of more civilised races in the north. These tribes, though differing in language and appearance from the Nile negro, were themselves no further advanced towards civilization than the inhabitants of the Upper Nile Valley, but they must have been already inured, or partially so, to the climate. The civilized races, however, appear to have stopped short in their southward progress along the Nile; they were not held up by any great geographical obstacle, for there was none; but must have been arrested by the climate, and the forbidding aspect of the country. This, I think, is the explanation of the fact that during a period extending over several thousands of years, you find primitive man living on the upper reaches of the Nile; and further north, on the banks of the same river, highly civilized races whose attainments in many directions have never been surpassed.

Neolithic remains found in various parts of Africa show that it was the scene of human activity at an early age. What type or types of man then inhabited the country, or how they were distributed, is so far unknown; however, in that part of Africa which is inhabited to-day by the darker races, two distinct and totally different sections of the great negro family are to be found-the Bantu, or perbaps more correctly, the Bantu-speaking native, and the Nilotic negro. Recent investigations have thrown some light on each, but for the moment I propose to deal with the Nile negra.

The traveller whose wanderings take him across the border line which divides the Bantu-speaking natives from the Nile negro, say from the shores of Lake Victoria to the neighbourhood of El Ducim or Wad Medani south of Khartum, cannot fail to be struck with the marked difference between these two great sections of the negro race. Each of these sections may be divided into many tribes showing various relationships both physical and linguistic, but the general types are still so far apart, as to suggest to my mind, that the primitive substratum of each was radically different. I may say at once that I merely offer here a suggestion; the history of Africa is so lost in obscurity, the questions are so complex, the period of time during which Africa appears to have been inhabited, so vast, in proportion to that of which we have even 


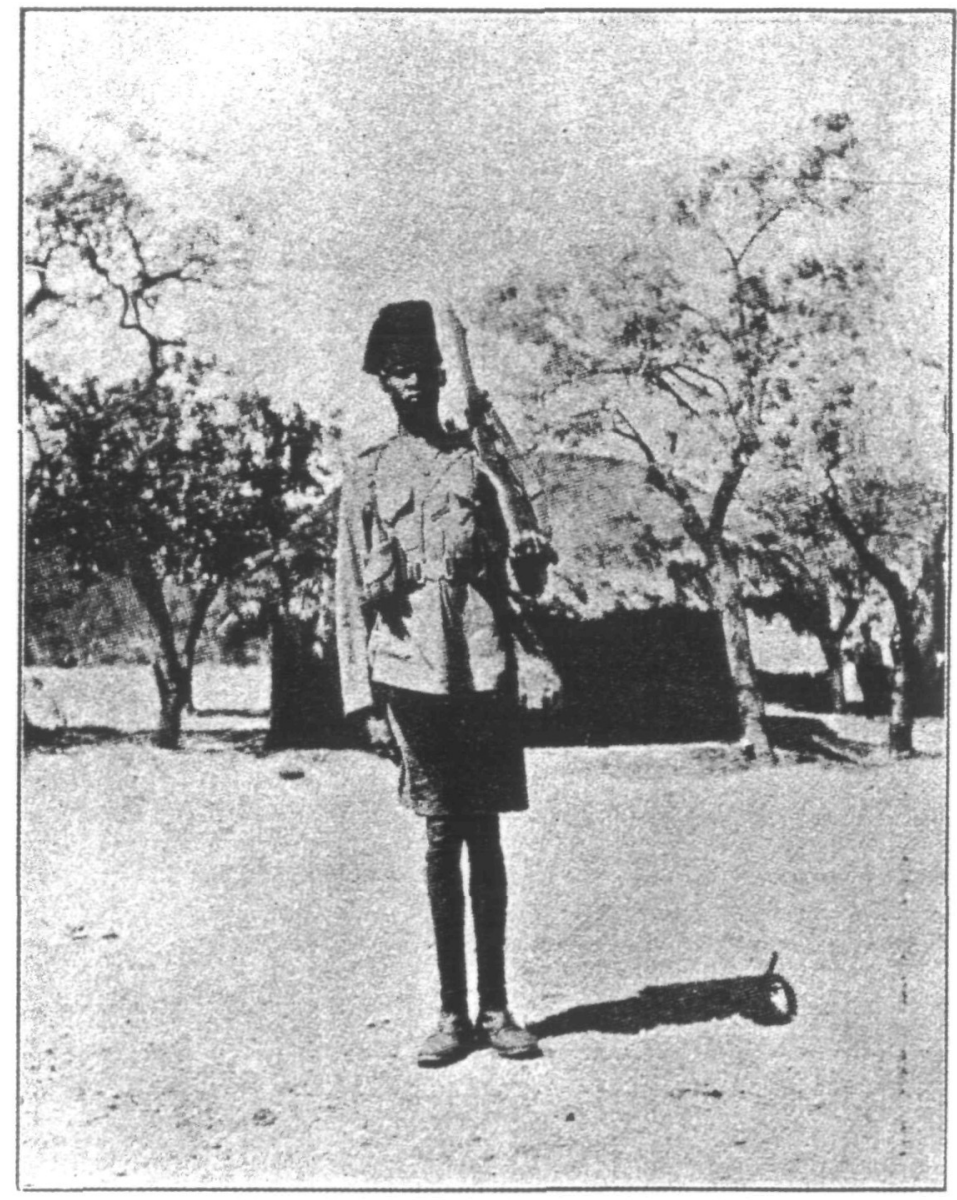

Typical Nilotic Negro, Full Face.

Note thin LeGs inclined tO TOUCH at KNEES.

To face page 166. 
$=$ 
the vaguest records, that, until a great deal more work has been done, any theory must be put forward with considerable hesitancy.

The knowledge, however, which has been.acquired in recent years appears to me to indicate, that the early inhabitant of the countries now peopled by Bantu-speaking tribes, may have been something of the Pigmy-Prognathous type.

A short, squat, coarse, and thick-set negro. It looks as if his country had been invaded by a higher type of negro, possibly from the west, and by a Hamite from the north-east, who was probably considerably tinged with negro blood before he reached so far south. There is ample evidence, in historic and recent times, of considerable and fairly continuous migrations. Arabs across the Red Sea, Galla as far south as Western Uganda (viz. Bahima), West African negro in the Sudan, and in all probability the process has been going on for thousands of years. Professor J. L. Myres traces four different Semitic intasions in North Africa, and the western influx, induced by the Mecca pilgrimage, has very likely been going on since the establishment of Islam.

It also appears to me, in the light of recent investigations, that in prehistoric days the Upper Nile Valley was inhabited by a very different type. He seems to have been very tall, probably black, prognathous, with receding forehead, and generally Simian in appearance; in fact, a true negro of very large proportions. Into this gentleman's domain, which may have extended from Lake Albert to the neighbourhood of Sennar, various races from east and north penetrated: Hamite, Galla, and more recently Semite from across the Red Sea. A casual observer might, indeed, be inclined to say that all the present Nilotic tribes are the descendants of one race, so striking and apparently uniform is the type, but that this is not the case is indicated by even the comparatively few measurements which have been taken, showing Cephalic indices ranging from 70 to 86 ; so there must have been, I think, in early times, at least two races, and possibly more. ${ }^{1}$

1 Anthropologints lay great stress on the cephalic index, ic, the rutio between length and breadth of the arull. How far cephalic index $b$ influenced by racial mixture is not yet certain. 
The Nilotic tribes of to-day, though they may be divided into various groups, have many curious and remarkable points in common which I propose to touch on presently.

The type is tall, very thin, the legs are long with undeveloped calves, inclined to be knock-kneed; prominent cheek-bones; the nose is, as a rule, flat and broad; there is seldom pronounced prognathism, the skin is very black, the hair woolly. In the matter of the skull the types vary from long to medium and broad, as mentioned above.

In one or two cases this type varies where there has been pronounced or recent Hamite mixture, as in the case of Latuka and Masai, both much lighter in colour, negroid rather than negro; but as a whole the long-legged Nile negro is a type quite distinct from the muscular, stoutly-built, and coarse-looking Bantu-speaking native.

It is an interesting question how far environment is responsible for the persistency of this type, which is practically constant from Lake Albert to the heart of the Sudan. Keane, in "Man Past and Present," says: "The human varieties are thus seen to be like all other zoological species, the outcome of their several environments; they are what climate, soil, diet, pursuits, and inherited characters have made them." How far, I wonder, will environment preserve a type in the face of frequent influx of new ingredients? It is hard to say, but in this case it is curious, that the land which supports the Bantu-speaking native, is as different in aspect and products, from the country of the Nilotic negro as are the two races themselves.

The change from the south, as the traveller crosses the Victoria Nile at Fajao, is immediate and remarkable; the whole of the Nile country is barren and unproductive when compared to the rich lands of Unyoro and Uganda; the rank elephant grass is found in places here and there and close to rivers, small patches of Dhura (Sorghum) replace the large planations of banana, sweet potato, Indian corn, and sugar cane. For the most part the undulating country is covered with thorn bush and stunted shrub, broken here and there by giant boulders poised at angles that appear to defy the force of gravity; at intervals a patch of brown reveals a native 


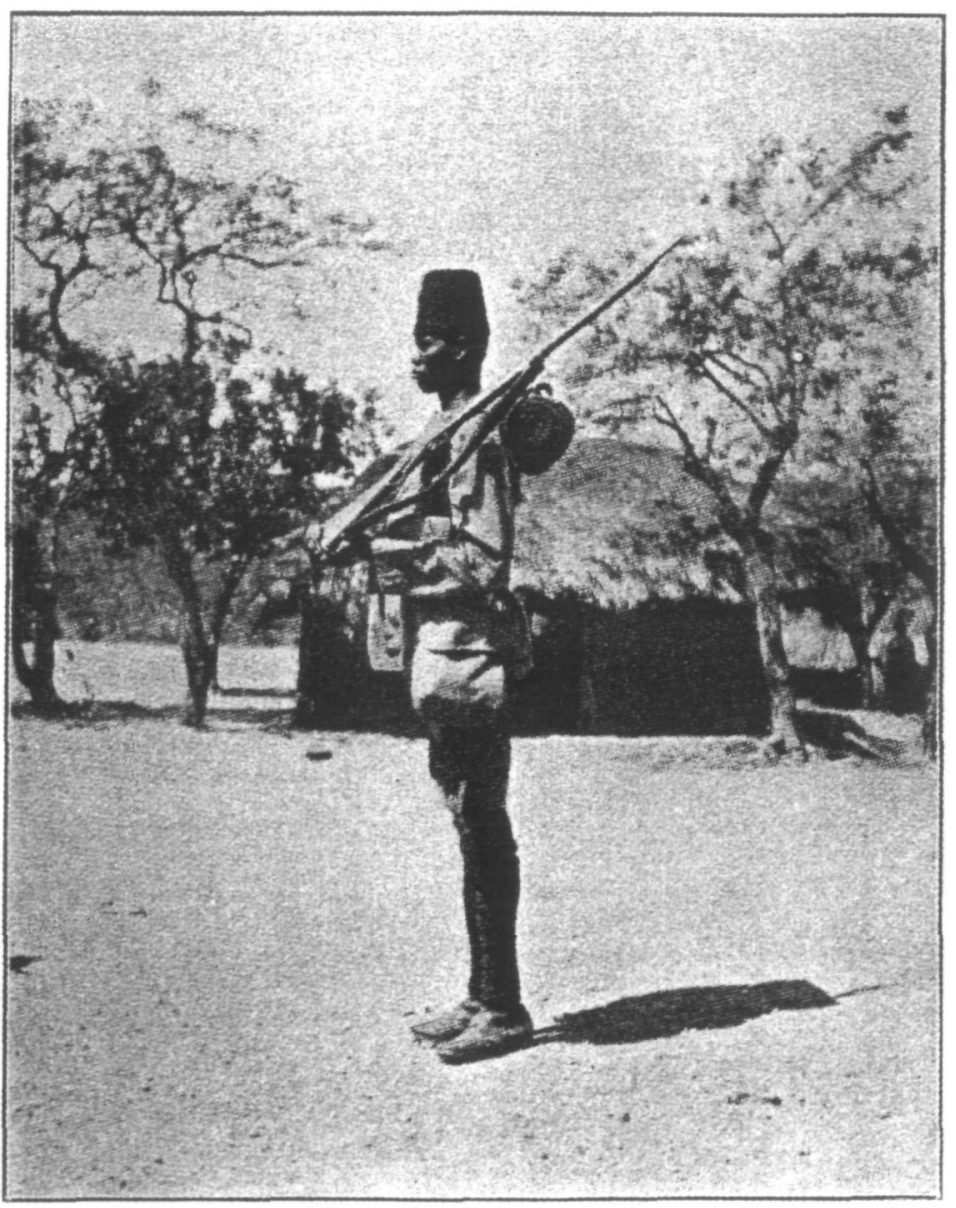

Typical Nilotic Negro, Side face.

Showing flattened Nose, prominent Cheek Bones.

To face page 169 . 

village. 1 The whole impression is lone and dreary, and the impression does not belie the reality, for man in these inhospitable regions, has ever had a fierce struggle with nature; at his best the Nilotic negro is indolent, and famine or plague have seldom been absent from one part of his country or the other.

I was stationed at Gondokoro some ten years ago; it happened to be a particularly dry season, no rain had fallen for months, and famine held the land in its grip. The pitiless sun shone day after day and week after week in a setting of liquid blue. It scorched and withered every crop, and dried up all the smaller rivers. In the country the natives were starving. The tall and emaciated Bari stalked abroad over the land like some wild animal in search of food; you met him on the roadside and in the jungle; hunger lent a lustre to his eye, which glared from a face drawn with exheustion and lined with suffering. If you went "on safari" the rear of your caravan was shadowed by these hungry skeletons hoping for a meal. It would come sometimes when Bushbuck or Hartebeest dropped to your rifie, and then even your orderly's muttered, "B'ism illahi," as he cut the throat, came spontaneously from the fullness of his heart rather than from his devotion to the Koran. This picture is no exaggeration, the Nilotic negro has always had a struggle for bare existence, for nature and inherited characteristics have been against him. It may be, then, that environment has played no unimportant part in maintaining this gaunt type so characteristic of the Nile negro, and so far removed from the sleek and well-fed Bantu.

I turn now to the book recently published on "The Shilluk People, their Language, and Folklore," by Mr. Westermann." The author has certainly made good use of his time. During a sojourn of only three and a half months in the Sudan he has compiled a very interesting and valuable work. His main object is linguistic. The book is divided into three parts :

1 There are patches here and there of good grass land and stretches of park land dotted with fine trees, especially near Mount Agoro, but these are the exception, not the rule.

- The'Shilluk Pcople, their Langwage and Folktore, by Diedrich Wextermenn, Berlin : Dietrich Reimer (Ernst Vohsen). 
Grammar, Folklore, and Dictionary; it might perhaps more aptly have been divided into four, for the introduction, which covers some forty pages, deals with the country and its people, gives a general sketch of their history, daily life, social customs, religion, and political institutions. This portion of the work will be read with considerable interest by anthropologists and all those interested in the Nile negro.

In reading these pages one cannot fail to remark on the curious persistence of some sociological and linguistic characteristics, which indicate intimate early relationship among Niloțic tribes now separated by vast tracts of territory. The method of making fire, perhaps, needs no comment, as it is much the same among most primitive peoples.

The pottery over the whole area of the Nile negro varies but slightly in design or shape, and, what is more curious, is that you can see pottery made to-day among many of the tribes identical with pottery some 3000 years old recently excavated in the Sudan.

The habitations, with one or two exceptions, show little variation. The Bari huts are built round a framework of upright stones about a foot high, and the Latuka huts are much higher in the roof, being bell-shaped and generally thatched with palm leaves instead of grass; with these two exceptions, all the huts I have seen along the White and Blue Niles are almost identical.

Again, as regards food, Dhura (Sorghum vulgare) seems to be the staple food throughout the whole area; the tribes supplement it with milk from cattle and goats. The author says, "The favourite occupation of the Shilluks is cattlebreeding; cattle mean wealth and social position, while the cultivation of the ground is merely the means of procuring daily food." The whole article on agriculture, pp. 99-102, is interesting, and might apply to most of the other tribes as far as Lake Albert. The story of the Bari is almost identical with that of the Shilluk; indeed, in the days prior to the invasion of Islam the valley of the Upper Nile must have been a great cattle country; even in quite recent times, a hundred years ago or so, many of the tribes owned enormous herds of cattle. Agriculture was never their natural vocation, 


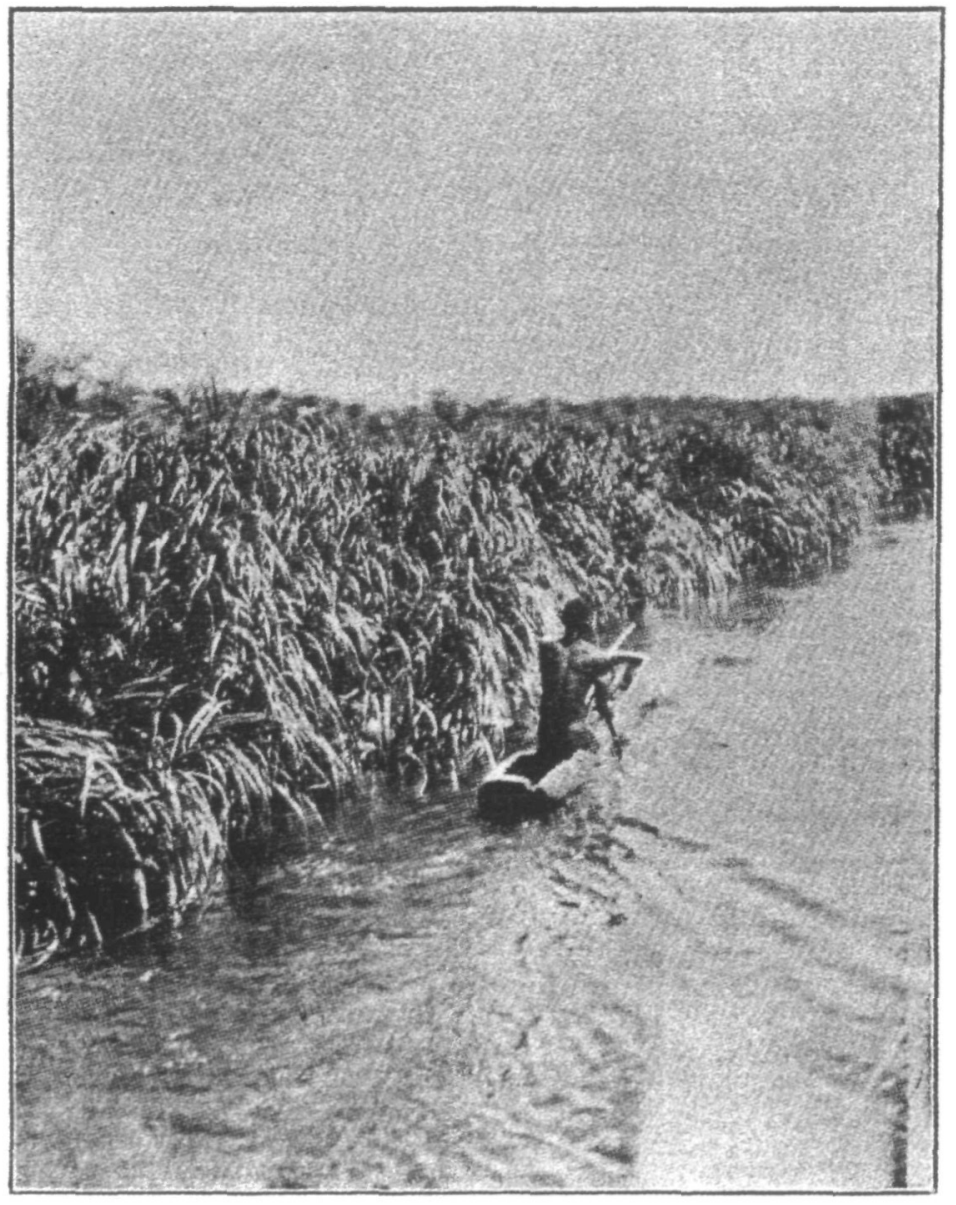

Native in Dug-out on Nile, amongst Sudd and Long Grass.

To face page 170 . 
- 
they cultivated the minimum possible, and relied on their cattle, goats, and sheep for principal sustenance; the truth is the country is grassland in large tracts, which intervene between the jungle covered with thorn bush, or forest, and the land which is rocky and barren. It is not suited for agriculture by reason of the poorness of the soil and the. inequalities in the matter of rainfall. This fact, that the Nilotic negro has been in the past a wanderer in the trail of his flocks, accounts to some extent for his migrations into East Africa and his general diffusion over so large an area. It is noteworthy in this connexion that offshoots of the Nile negro, such as Masai and Jaluo, did follow from pasture to pasture, and remain to-day pastoral tribes. So far as I know, no large settlement of Nile negro, or the descendant of Nile negro, is to be found in the essentially agricultural lands where the banana and sweet potato flourish.

In the matter of clothing, or want of it, the same uniformity appears in all the tribes uninfluenced by the Semitic invasion across the Red Sea. From this it would seem that the Hamite, whose mixture with the Nile negro produced the Masai and such types (Sir Harry Johnston says, "Some fusion between Hamite and Nile negro created the Masai and such types"), and, I might add, the Latuka, must have worn as little clothing as do these tribes.

The author notes the extraction of the lower incisors; this is a remarkable trait of the Nile negro and extends with one or two exceptions down to the Masai in East Africa. It is practised to-day by various tribes on the White Nile, and was practised some 3000 years ago by the curious race recently excavated at Gebel Moiya, as Dr. Douglas Derry showed in his lecture at the Anthropological Society on the 1oth December. In this case it was principally done by the women who wore a lip stud, and presumably the teeth were extracted to make way for the ornament. Dr. Derry mentioned the apron made of beads found in the graves of young girls; these aprons are identical with the "rahad" worn by Muhammadan Sudanese to-day, except that the rahad worn to-day is made of strips of tanned goat skin; it is only worn by unmarried girls, and this appears to have been the case 
also with the people of Gebel Moiya. I was much surprised to see these bead aprons, because I had always associated the "rahad" with Islam. I have never seen it worn by Dinka Shilluk, Bari, Madi, or any pagan tribe, but apparently its introduction is far older than the religion of Muhammad. The extraction of the lower incisors is another link in the chain which connects the Masai in East Africa with the Nile negro.

The custom of burying inside or at the entrance to the hut prevails among Lur, Lendu, Baka, Mundu, and many tribes both east and west of the Nile. In the King's African Rifles in Uganda we had considerable difficulty in stamping out the practice, and I remember on one occasion, long after the habit was supposed to have been exterminated, an order was issued to remove a large village occupied by our Sudanese soldiers; when the village had been removed, the ground presented the appearance of a large graveyard.

The peculiar form of hairdressing among the Shilluk resembles that of the Langu, but the latter is more elaborate and stretches like a shield down the back. In this respect both tribes differ from any others I have seen.

The Deity Jok is known to Lur, Acholi, and, if I mistake not, to Lendu also. The connexion between the Acholi or Shuli and the Shilluk is very evident, as pointed out by $\mathrm{Mr}$. Westermann, nearly all the names of villages in the Shuli country begin with FA or PA-Falabek, Fadibek, \&c. This word, the author points out, means "home or village" in the Shilluk language. The political institutions of the Shilluk seem to be an advance on the other Nilotic tribes; as a rule these tribes have many chiefs but no king, and no elaborate court or semblance of royalty is met with till south of the Victoria Nile in the Bantu kingdoms of Unyoro and Uganda. The population of the Shilluk to-day, Mr. Westermann says, is 60,000 , but forty years ago it was given as a million, and, he adds, "such a decrease is hardly thinkable."

In all probability the million was a very generous estimate, but the ravages of smallpox, famine, incessant fighting, slave

\footnotetext{
1 Dr. Derry in his lecture mentioned that the archaeologists considered the people
} excarated at Gebel Moign to be about 3,000 years old. 
raids, and a decade of Dervish rule, would be sufficient to account for the loss of a very large percentage of the population; under somewhat similar conditions, the Bari, between the years 1860-1900, lost, according to their own account, about three-fourths of their numbers. Smallpox has always been a terrible scourge over all this country, for nothing will induce the native to believe that it is necessary to segregate. The Dervish occupation, too, acted as a blight on the land; they kifled and captured thousands of natives, and the numbers exported to the north by slave traders must have been very considerable indeed. On the whole, then, I am inclined to believe that at one time not so very distant the whole of this Upper Nile Valley was densely populated, and what we find to-day are but a very small percentage, the survivors of what Winwood Read called "the martyrdom of man."

In discussing the migrations and history of the Shilluk, the author raises the interesting question of the origin of the Fung. He seems inclined to think, on the authority of Bruce, James, and Cailliaud, that the Fung and Shilluk are identical. This I do not believe. The origin of the Fung, and the former history of Sennar, are vexed questions which have been engaging the attention of many men on the spot for some years past. The Fungs themselves say that they came from the Yemen, that their ancestors were the Beni Ummiah who crossed the Red Sea in the neighbourhood of Massawa or Suakin about 130 years after the-foundation of Islam, penetrated into Abyssinia, and settled at Gebel Gulli (also called Gebel Idris), that they spread over the Burun country, and married freely with Shilluk and Hamag ; finally, about the $15^{\text {th }}$ century, they conquered the Hamag, and spreading northward, became masters of the Sennar province.

It is, of course, misleading, especially in a country like the Sudan, where a "nisbah," or pedigree, is as much prized as it is in Western Europe, to rely on the statements of any tribe as to its origin, but some weight must be attached to a consensus of native opinion which seems to be very general.

Yuzbashi Ahmed Hussein, the Mamur of Sennar, has 
collected much information on this subject, and Sheik Omar, one of the last of the Fung princes, informed me with considerable emphasis that his ancestors were as white as we are. This old man's appearance was negro, but if his maternal relatives for some generations past were Hamag, Shilluk, Burun, or some other negro tribe, then the statement, on the face of it apparently impossible, may not be so far from the truth. However this may be, it is well to bear in mind that many of the tribes who now inhabit the Ghezirah (country between the White and Blue Niles, south of Khartum), such as Arageen, Dogheim, Kawahila, \&c., claim relationship with Beni Ummiah, Beni Asad, and others whose original home was in the Hedjaz, and it is, of course, common knowledge that following on the establishment of Islam there was a very great influx of Arabs across the Red Sea into the Sudan. I may add that there is no apparent physical distinition to-day between the Fung and the Hamag, but little can be said with any certainty on this subject, nor on the subject of the relationship which exists between the various negro and negroid tribes in the valley of the Upper Nile, till accurate anthropometric measurements of sufficient numbers of these tribes have been taken. Such measurements as have been recorded, seem to indicate a close relationship between Shilluk, Dinka, and Nuer. An anthropological expedition from Khartum to Lake Albert would yield magnificent results, and would throw much light on many problems connected with the Nile negro whose solutions become more difficult with every year that passes.

Mr. Westermann says : "The physical appearance of the Shilluk is not that of pure negroes; they might rather be called negroids, in spite of their dark colour." I think "negroid" would be more correctly applied to tribes I have seen further south, such as Latuka, Masai, where a distinct foreign element is noticeable, in their case Hamite, or to tribes like the Bahima and Somali, of Galla extraction. Dr. Douglas Derry, anthropologist at University College, London, who has worked in Egypt and the Sudan, is of opinion that "negro" correctly describes the Shilluk.

To sum up, then, I am inclined to believe that the ancestors 
of the Bantu-speaking peoples and the ancestors of the Nilotic negro tribes were two very different types of negro, and I would be inclined to say that the indications point to two early races, both tall and gaunt, but one dolichocephalic, the other brachycephalic, from whom most, if not all, of the present-day tribes on the Upper Nile are descended. The reasons for this suggestion are:-

1. The general type is constant over the whole area.

2. They are all pastoral people, found on grass lands.

3. The measurements give cephalic indices which show at least two distinct races.

4. They all show the same modesty, or want of it, by western standards, in the absence of clothing.

5. They show a proclivity to extracting the lower incisors and burying in sitw.

6. They have many sociological and linguistic affinitiesmany more than I have touched on in this paper.

As regards the language, Mr. Westermann's work will be of great service to missionaries and others, and will save the future student much time and labour; but it is a good illustration of the difficulty attending the use of our alphabet to reproduce a totally distinct set of sounds. The author remarks: "As in other Sudan languages, the intonation is an important and essential part in Shilluk grammar." This is equally true of some Bantu tongues. Mr. Westermann has endeavoured to reproduce faithfully accent and intonation, but I fear the result is sufficient to dishearten any but the most energetic and determined pupil. A new alphabet would be simplicity itself in comparison with this English alphabet distorted by the aid of diacritical marks placed above and below almost every vowel and consonant. The Baganda missionaries have produced excellent grammars of the Luganda language in which intonation, except in rare cases, is ignored, though intonation plays no mean part in the language. It is considered, and I think rightly, that intonation can be acquired by the student on the spot, as the ear gets accustomed to the sounds, and that these written grammars and vocabularies must always remain what, as a 
rule they are intended to be, merely aids to the rapid acquiring of the language through the ear. Despite this drawback, I think Mr. Westermann is to be congratulated on a work which is a valuable addition to our knowledge and contains much interesting matter for the general reader.

J. A. Meldon. 